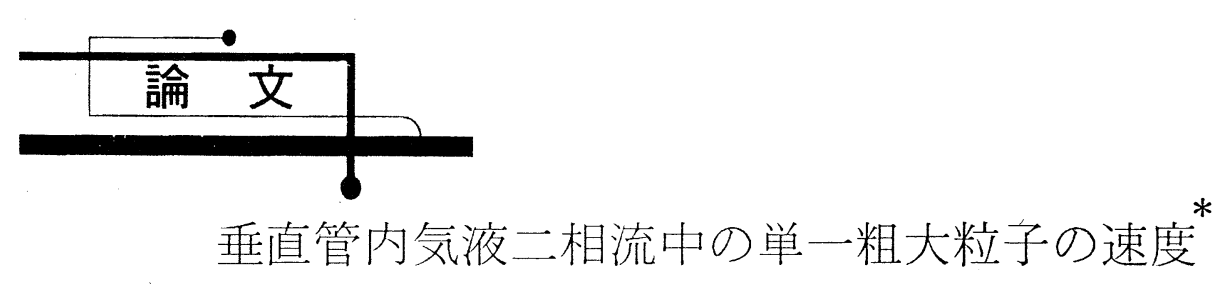

\title{
Velocity of Single Coarse Particle in Two-Phase Gas-Liquid Flows in a Vertical Pipe
}

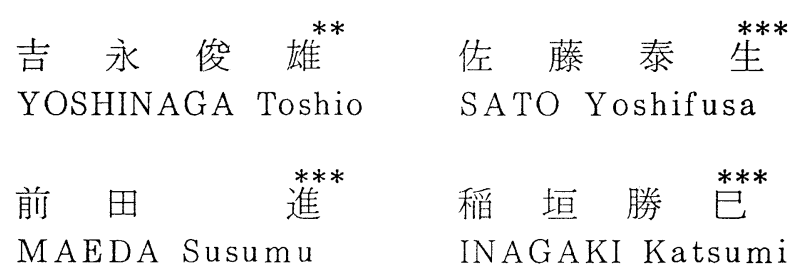

\begin{abstract}
A bstract The velocity of single particles in air-water two-phase flows has been investigated. The geometrical shape of the test particles were sphere and cube; their size ranged in volume-equivalent diameter from 4 to $10 \mathrm{~mm}$; their density ranged from 1190 to $7850 \mathrm{~kg} / \mathrm{m}^{3}$. The volumetric fluxes of air and water varied within the ranges of $0 \leqq j_{G}<10 \mathrm{~m} / \mathrm{s}$ and $0 \leqq j_{L}<1.5 \mathrm{~m} / \mathrm{s}$, respectively. The velocity of the particles in a vertical pipe of $26 \mathrm{~mm} \mathrm{I.D.} \mathrm{was} \mathrm{measured} \mathrm{using} \mathrm{a} \mathrm{pair} \mathrm{of} \mathrm{metal} \mathrm{detectors.} \mathrm{Both} \mathrm{air} \mathrm{and} \mathrm{water}$ velocities at which the particles float in the pipe were also measured. A simple model to correlate particle velocity with two-phase flow parameters is presented, based on the experimental data of spherical particles. The proposed model is compared with the data of cubic particles and shows good agreement.
\end{abstract}

Keywords: Multiphase flow, Three-phase flow, Two-phase gas-liquid flow,

Particle velocity, Hydraulic transportation

\section{1. 緒言}

近年、海底鉱物資源であるマンガン団塊の採鉱を目的として、気泡ポンプを利用することが 考えられている。この方法によりマンガン団塊を揚鉱するとき、管内の流れは空気導入部を境 として固液二相流と固気液三相流となる。固液二相流は固気二相流と共に古くから研究されて

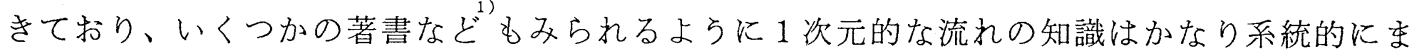
とめられている。これに比べ固気液三相流については、固体の輸送といら観点からみると、坂 ロが指摘するように゙未知の分野であり、今後研究され解明されねばならない課題が多数残さ れている。

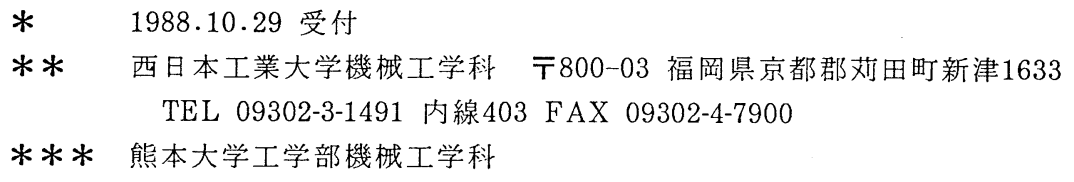


三相流中の粒子群の速度もこの一つである。粒子群の速度の情報は、三相流の基礎方程式を 解くための構成式の選択に拈いて必要であるし、揚鉱管の損傷やマンガン団塊の破壊状況の推 定など実用面からも重要である。この粒子群の速度に関しては、気液二相流中の単一粒子の速

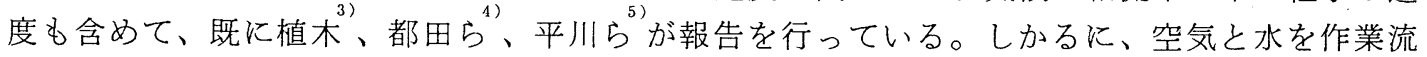
体とする垂直管内の三相流に限定しても粒子速度に関与する因子は多い。重要なものとしては 気水の容積流束、粒子の濃度・密度・形状、管路の内径と粒子寸法の比などが挙げられる。こ のため、適用範囲の広い粒子速度の整理式を得るには、過去に報告されているデータのみでは

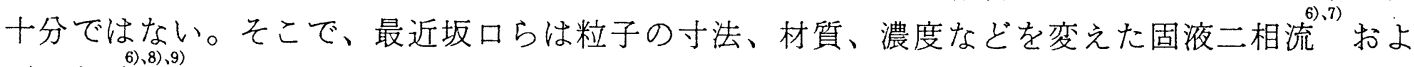
び三相流(8).97 $の$ 実験を行い、系統的なデータを提供している。彼らは粒子群は液相内に存在す るという仮定のもとに粒子速度の実験式の組み立てを試みているが、現在をでのところ十分説 得力のある表示式の構築には至っていない。

上に述べたように三相流では関与因子が多いので、ある従属変数（たとえば粒子速度）に及 ぼす他の因子の影響を抽出することは容易ではない。そこで、三相流そのものに関する実験と 並行して関与因子の数を減らした実験は三相流の特性を把握する手掛かりを与学かものと思わ れる。このような観点から、著者らは気液二相流における単一粒子の挙動に着目し、その速度 測定法を確立すること、および粒子速度と主流動パラメータとの関係を調べることを目的とす る実験を行った。本報においては、をず単一粒子の速度のデータを提示する。次に、粒子速度 を主要パラメータとの関連において推定する一つのモデルを提案する。

記号

\begin{tabular}{llcllr}
$A$ & 管路断面積 & {$\left[\mathrm{m}^{2}\right]$} & $u$ & 速度 & {$[\mathrm{m} / \mathrm{s}]$} \\
$c$ & 式 $(2)$ の係数 & {$[-]$} & $u_{S R}$ & \multicolumn{2}{c}{ 式 $(2)$ の $\mathrm{u}_{F}=0$ に打る } \\
$C_{D}$ & 抗力係数 & {$[-]$} & & $u s$ 軸上の切片 & {$[\mathrm{m} / \mathrm{s}]$} \\
$D$ & 管内径 & {$[\mathrm{m}]$} & $u_{S W}$ & 壁面干渉沈降速度 & {$[\mathrm{m} / \mathrm{s}]$} \\
$d v$ & 粒子の球相当径 & {$[\mathrm{m}]$} & $u_{S \infty}$ & 自由沈降速度 & {$[\mathrm{m} / \mathrm{s}]$} \\
$g$ & 重力加速度 & {$\left[\mathrm{m} / \mathrm{s}^{2}\right]$} & $x$ & クオリティ & {$[-]$} \\
$G$ & 質量流量 & {$[\mathrm{kg} / \mathrm{s}]$} & $\alpha$ & ボイド率 & {$[-]$} \\
$j$ & 容積流束 & {$[\mathrm{m} / \mathrm{s}]$} & $\beta$ & 気体容積流量比 & {$[-]$} \\
$\tilde{j}$ & 浮遊容積流束 & {$[\mathrm{m} / \mathrm{s}]$} & $\nu$ & 動粘度 & {$\left[\mathrm{m}^{2} / \mathrm{s}\right]$} \\
$R e s$ & 粒子レイノルズ数 & {$[-]$} & $\rho^{2}$ & 密度 & {$\left[\mathrm{kg} / \mathrm{m}^{3}\right]$} \\
$t$ & 時間 & {$[\mathrm{s}]$} & $\rho_{E}$ & 実効密度 & {$\left[\mathrm{kg} / \mathrm{m}^{3}\right]$}
\end{tabular}

添字

F 流体

$S$ 固体

G 気体

$T P$ 気液二相流体

$\mathrm{L}$ 液体

\section{2. 実験}

\section{1 供試粒子}

供試粒子の諸元をTable 1に示す。粒子名は略号で示してあり、初めの 2 文字が粒子の材質、 ハイフンの後の 1 文字が形状、最後の 2 文字が寸法を意味する。また、略号名にォ印の付して ある粒子は、後述の金属通過センサーによる速度測定のできない非金属粒子である。粒子の幾 何学的形状は球形と立方体の 2 種類であり、密度は $1190 \sim 7850 \mathrm{~kg} / \mathrm{m}^{3}$ の間で 4 種類とした。粒 
Table 1 Details of test particles

\begin{tabular}{|c|c|c|c|c|c|}
\hline Particle & Shape & Material & $\begin{array}{l}\text { Density } \\
\rho_{\mathrm{s}} \mathrm{kg} / \mathrm{m}^{3}\end{array}$ & $\begin{array}{c}\text { Size } \\
d_{v} m m\end{array}$ & $\begin{array}{l}\text { Coefficient } \\
\text { of Drag } C_{D}\end{array}$ \\
\hline $\mathrm{AC}-\mathrm{S} 08^{\star}$ & \multirow{9}{*}{ Sphere } & Acrylate & 1190 & 8.0 & \multirow{9}{*}{$0.42 \pm 0.06$} \\
\hline $\mathrm{A} 1-\mathrm{S} 06$ & & \multirow{2}{*}{ Aluminum } & \multirow{2}{*}{2690} & 6.1 & \\
\hline A1-S10 & & & & 10.0 & \\
\hline C1-S06* & & \multirow{3}{*}{ Ceramics } & \multirow{2}{*}{2540} & 6.0 & \\
\hline $\mathrm{C} 1-\mathrm{S} 10^{*}$ & & & & 10.0 & \\
\hline $\mathrm{C} 2-\mathrm{S} 06^{*}$ & & & 3630 & 6.0 & \\
\hline St-S04 & & \multirow{3}{*}{ Steel } & \multirow{3}{*}{7850} & 4.0 & \\
\hline St-S06 & & & & 6.0 & \\
\hline St-S10 & & & & 10.0 & \\
\hline $\mathrm{A} 7-\mathrm{C} 06$ & \multirow{2}{*}{ Cube } & \multirow{2}{*}{ Aluminum } & \multirow{2}{*}{2690} & 5.9 & \multirow{2}{*}{$1.16 \pm 0.12$} \\
\hline Al-C10. & & & & 9.9 & \\
\hline
\end{tabular}

子の寸法は、粒子と同体積の球の直径（球相当径 $d$ 。と呼ぶ）で示してある。（管径比 $d v / D$ は 0.154〜0.385の範囲となっている。)

表中の抗力係数 $C_{D}$ の值は、壁面の影響のない静止流体中を沈降する粒子の終端速度（自由 沈降速度 $u s \infty$ と呼ぶ）の実験值を次式に代入して求めた平均值である。

$$
u_{S \infty}=-\left[\frac{4 d_{V} g\left(\rho_{S}-\rho_{F}\right)}{3 C_{D} \rho_{F}}\right]^{0.5}
$$

ここで、 $\rho_{S}$ および $\rho_{F}$ はそれぞれ粒子と流体の密度であり、速度は鉛直上向きを正としている。 $u s \infty$ の值は、内径 $300 \mathrm{~mm}$ 、長さ $1.2 \mathrm{~m}$ の透明なアクリル管内の静止水中を壁面に接触せずに 自由落下する粒子をビデオカメラで撮影することによって求めた。測定はそれぞれの粒子につ いて20〜30回行った。粒子レイノルズ数Res $\left(=u s \infty d v / \nu_{L}\right)$ は. $0^{3} \sim 2 \times 10^{4}$ の範团で、ニュー トンの抵抗法則にしたがら領域にあった。得られた抗力係数 $\mathrm{C}_{D}$ の值は、球についてはSchlichting の本に示されている値、立方体についてはWadellの結果 ${ }^{11}$ と良く一致した。

\section{2 実験装置}

実験装置の概略をFig.1に示す。供試管には内径 $26 \mathrm{~mm}$ 、全長 $5.4 \mathrm{~m}$ の透明なアクリル管を用 い、これを鉛直に立てた。作業流体は常温の空気と水であった。水はポンプより送り出され、 流量調整バルブで流量を調整されて装置下部より導入された。コンプレッサーから送られてき た空気は、空気流量計で流量を測定されたのち、水導入部より $0.6 \mathrm{~m}$ 下流で二重管式の小孔群 から水の流れに吹き込まれた。なお、空気の容積流束 $\mathrm{j}_{G}$ は、測定部（次に述べる 1 対のセンサー 間の区間) の中央位置における值とした。

粒子は、これが上昇する場合には、空気吹き込み部より $0.57 \mathrm{~m}$ 下流で手動ピストンにより流 れの中に押し込まれた。粒子速度は、1.8mの助走区間を経たのち、 $1.57 \mathrm{~m}$ 距離で設けられ たセンサーU1とセンサーU2の間の通過洔間を測定することで求めた。テストセクションを通 過した空気、水および粒子は装置上部で分離され、空気は大気中に開放され、粒子は回收され、 


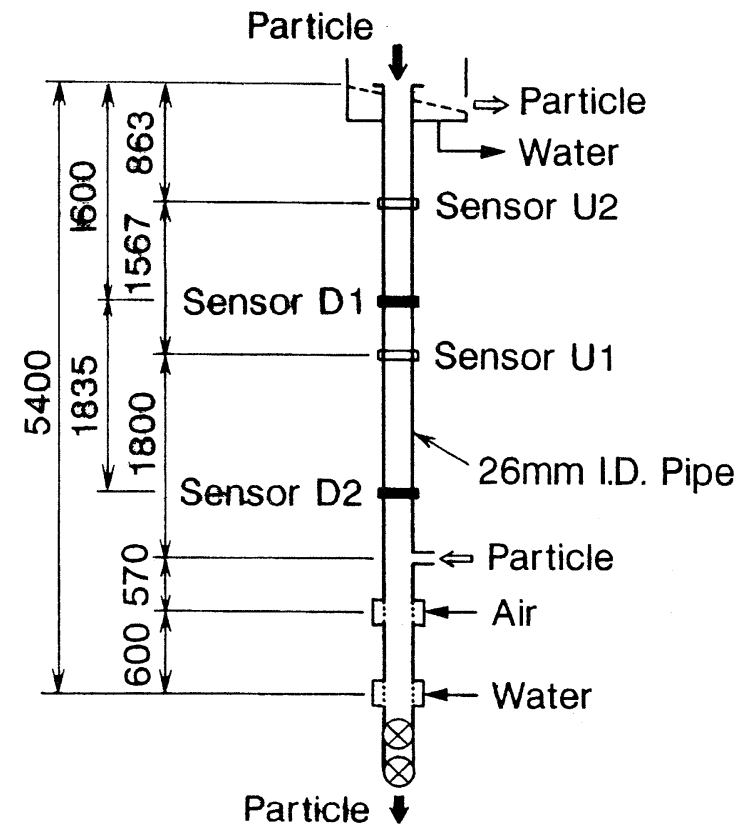

Fig. 1 Experimental apparatus

水は量水槽に導かれた。粒子が下降する場合には、黒の矢印で示すように、装置上部より導入 され、 $1.6 \mathrm{~m}$ の助走区間を経たのち、間隔 $1.84 \mathrm{~m}$ の二つのセンサーD1とD2間の通過洔間が測定 され、装置下部より回収された。

センサーには、光電スイッチと金属センサーを使用した。光電スイッチは視別できる粒子に 有効であるため(応答時間 $1 \mathrm{~ms}$ 以下)、本研究では主として水単相流の実験に用いた。金属セン サーは、光電スイッチで視別できない気液二相流中の粒子の検知に使用した。ただし、供試粒 子は磁性を有するものに限定された。なお、水単相流中の粒子速度をこの二種類のセンサーを 用いて同時に測った結果、両者の值は $0.5 \%$ 以内で一致した。

粒子を導入してから観測部に達するをでの助走距離は、前述のように $1.8 \mathrm{~m}$ と $1.6 \mathrm{~m}$ とた。 設定した助走距離の妥当性を次の要領で確認した。本実験で粒子の速度が最大となる流動条件 $\left(j_{G}=8 \mathrm{~m} / \mathrm{s}, j_{L}=0.75 \mathrm{~m} / \mathrm{s}\right)$ に打いて、1 対のセンサ一の位置を流れ方向に変化させその都度 粒子速度を調べた。この結果、粒子速度は、設定した助走距離付近で汪ぼ一定值に漸近してい ることが確かめられた。

水単相流中の粒子速度は水流速と同程度の小さな変動しか示さないと考えられるが、気液二 相流中の粒子速度は水単相流に比べるとはるかに大きく変動する。Fig. 2は、 $j_{G}=1 \mathrm{~m} / \mathrm{s}, j_{L}=0.3$ $\mathrm{m} / \mathrm{s}$ のスラグ流に打ける粒子の速度変動を調べた例である。粒子の動きを追跡しやすい流動条 件を選び、測定部中央付近の約 $0.3 \mathrm{~m}$ の区間をビデオカメラで撮影することにより粒子速度を 求めた。図の横軸はビデオの送り洔間、縦軸は 1 コマめたり $(1 / 30$ 秒) の移動距離より求めた粒 子速度を示している。実線は、同一粒子の一コマあたりの速度の变化を順次結んだものである。 破線は、先行する粒子がここで両面より消え、先行するものと $0.2 \mathrm{~m}$ 以上離れた後続の粒子に 測定対象が変わったことを示している。（図では、便宜上、先行粒子と後続粒子の横軸の間隔 は一コマに取り、一個の粒子の連続的な速度変動のごとく表示してある。）1/30秒の間の粒子 


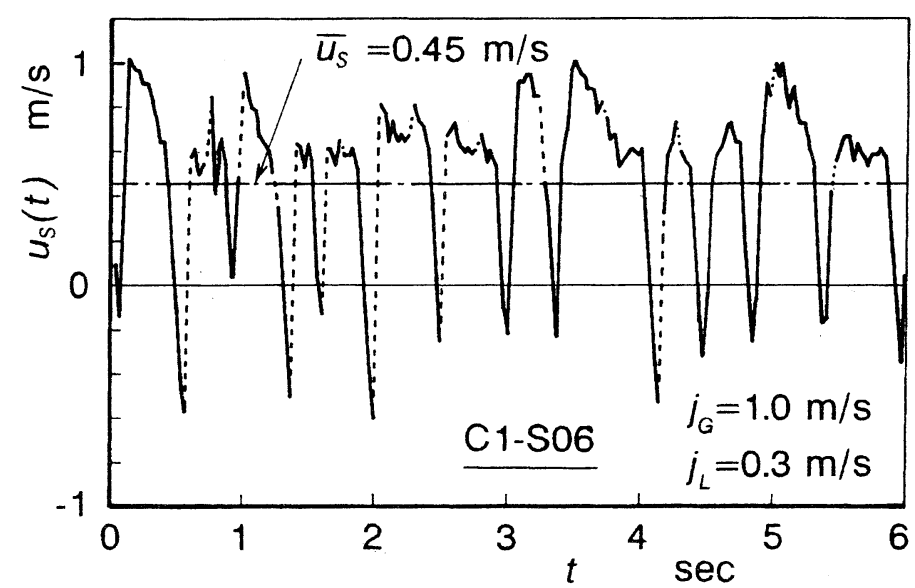

Fig. 2 Variation of particle velocities in a typical two-phase slug flow (measured by video camera)

速度の変化が非常に大きく、時間平均的には上昇しているものでも一洔的には下降することが ある。これらの速度変動は、粒子が液体スラグ部にあるか、気体スラグ部にあるかに対応して いる。本論文では、図中に一点鎖線で示す粒子速度の平均值に注目する。なお、Fig.2 提示 した一連の粒子の静止水中における $u s_{\infty}$ は、測定誤差の範团内で互いに一致した。

Fig.3は、Fig.2の粒子速度が、時間平均の結果として徐々に平均值へ収束する様子を示した ものである。横軸はビデオの送りであり、縦軸は横軸のコマ数索での速度の算術平均值である。 図中にはAとBの二つの異なる時間帯のデータの収束状況が実線で示されている。350בーマ以 上になると二つの実線は一致し、一点鎖線で示す平均值に收束していることが分かる。これは 12秒間に相当する。このことから、気液二相流に関する本実験において金属通過センサーで粒 子速度を測定する際には、実測定時間の総計が 12 秒を十分越える個数 (粒子速度とその变動量 の大きさに応じて、一つの流れについて15～100個)の粒子についてデータを採取し、その平均 值を求めた。

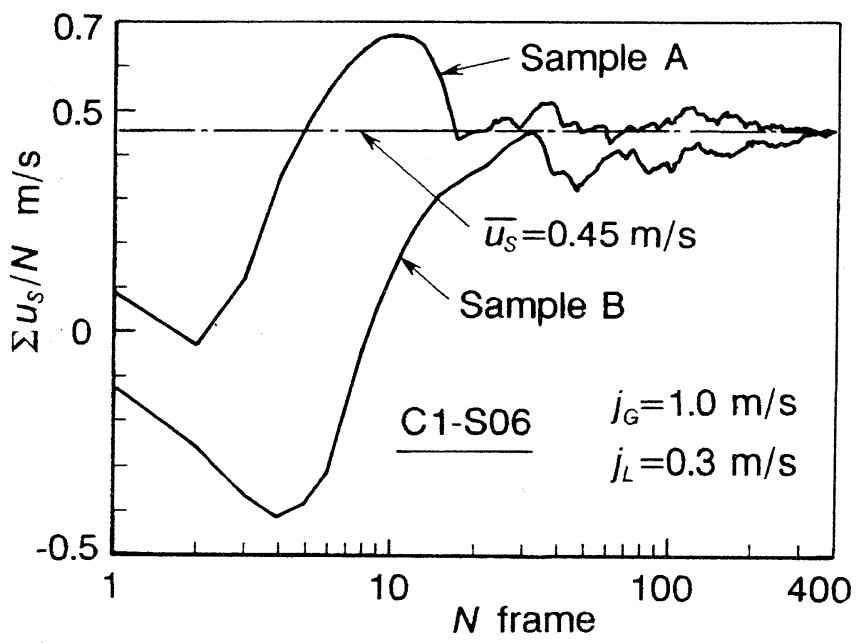

Fig. 3 Relation between the number of sample $\mathrm{N}$ and the particle velocity averaged over $\mathrm{N}$ 
以上の流体中を輸送される粒子速度のほか、粒子を同一位置に浮遊停滞させる浮遊容積流束 も測定した。

\section{3. 結果亡考察}

\section{1 水単相流中における粒子速度}

管内液単相流中の粒子速度については、粒子群の速度まで含めるといくつかの実験結果や予

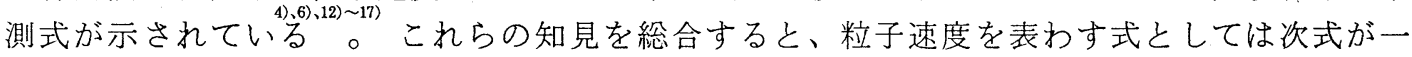
般性を有していると思われる。

$$
u s=c u_{F}+u s R
$$

ここで、右辺第 1 項は流体の代表速度 $u_{F}$ で運ばれる速度の成分、第 2 項は $u_{F}=0$ における $u s$ 軸上の切片である。係数cは、流体の速度分布の形、粒子の寸法、粒子の流路断面内の存在位 置などで異なる值を取ると考えられる。ちなみに、都田ら ${ }^{12)}$ は1.23、Govierら ${ }^{13}$ は1.10、Engelmann 1.22 としている。流体の代表速度としては、液単相流では次式の容積流束が適当であ ろう。

$$
u_{F}=\frac{G_{L}}{\rho_{L} A}=j_{L}
$$

ここで、GLは質量流量、Aは管路断面積である。

Fig. 4 は、形状、比重、寸法の異なる数種の供試粒子の速度の実験結果を、水の容積流束 $j_{L}$

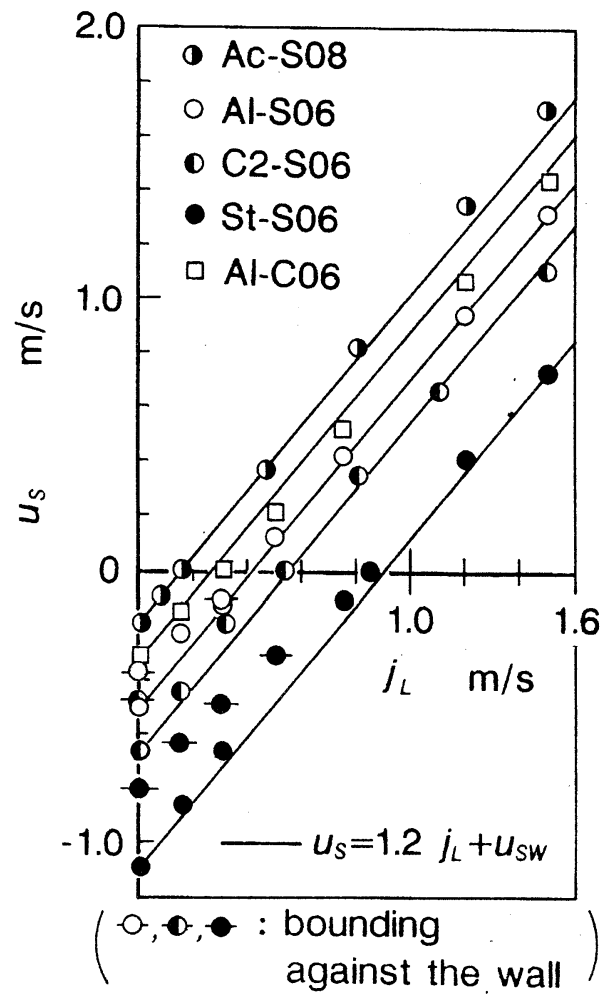

Fig. 4 Experimental data on particle velocity in single-phase liquid flows 
に対して示したものである。水単相流中を下降する粒子には、ジグザグ運動によって壁面で跳 ねる粒子と(この粒子のデータはFig.4中の記号に横線を付してある)、泀ぼ管中央部を通過し 時折壁面に接触して落下する粒子とがあった。このうち前者の出現確率は、 $j_{L}=0.5 \mathrm{~m} / \mathrm{s}$ の鋼 球のデータを除くと、最大でも $15 \%$ 以内でその確率は低かった。さらに、そのような粒子は $u s>0$ 領域では見られなかった。実線は、式(2)の係数を $c=1.2$ とし、 $u s R$ を管内の静止水 中の管中央部を落下する粒子の終端速度（壁面干渉沈降速度 $u s w$ と呼ぶ）とした計算結果であ る。実線と実験值は比較的よく一致しており、本実験に用いた粒子の水単相流中の速度は、シ グザグ運動によって壁面で跳ねて下降する粒子を除くと、次式で表すことができる。

$$
u s=1.2 j_{\mathrm{L}}+u s w
$$

ところで、壁面干渉沈降速度 $u s w k は$ 多くの提案式があるが(代表的には文献18)～21)）、 ここでは粒子レイノルズ数Res $\geqq 100 て ゙$ 有効である鮎川ら ${ }^{19)}$ の提案式を修正した式(5)を用いた。 式(5)は、鮎川らが無視した右辺第三項の微小項を、 $d_{v} / D=1$ のときに $u s w=0$ となるよらに係 数を選んで考慮したものである。

$$
\left(\frac{u_{S W}}{u_{S \infty}}\right)^{2}=1-2.5\left(\frac{d_{V}}{D}\right)^{2}+1.5\left(\frac{d_{V}}{D}\right)^{4}
$$

式(2)の $u s_{R} に$ 代えて浮遊速度を用いる説があるが、著者らはこの説を否定するものではな い。 $u s$ と $u F$ の間に直線的な関係があれば、 $u s R$ であれ浮遊速度であれ $u s$ と $u_{F}$ の実験值から 同じように求まる。

\section{2 気液二相流中における粒子速度}

\section{(1) 実験結果}

Fig. 5(a)，(b)k気液二相流中の粒子速度 $u s$ の実験結果の一例を示す。供試粒子はそれぞれ 直径 $6 \mathrm{~mm}$ のアルミニウム球と鋼球である。図は全容積流束 $\left(j_{G}+j_{L}\right)$ の変化に対して $u s か ゙$ ぞのように変わるかを示している。パラメータは水の容積流束 $j_{L}$ であり、実験点にはTaitel ら による流動様式の判別結果を加味している。黒塗りの点は水単相流中の粒子速度の実験点 で、破線がこれに対応する式(4)を示している。同一の全容積流束 $\left(j_{G}+j_{L}\right)$ のもとでも粒子 速度 $u$ sは水の容積流束 $j_{L}$ の值によって相違する。すなわち、 $j_{L}$ が増大するにしたがって $u s$ が高くなっており、ボイド率が下がり気液二相媒体の密度が高くなった効果が現われたものと 思われる。

粒子速度 $u s$ と全容積流束 $\left(j_{G}+j_{L}\right)$ の関係は直線的ではない。したがって、式 $(2)$ において $u_{F}=j_{G}+j_{L}$ としてよい保証はない。このことは固気液三相流における固相の速度を $u_{s}=c$ $\left(j_{G}+j_{L}+j_{S}\right)+u_{S R}$ で表わすことの不利・不便さを示唆している。言うまでもなく、（ $j_{G}$ $\left.+j_{L}+j_{S}\right)=$ 一定值を与える各相の容積流束の組合せは無数あり、その組合せいかんで $c$ と $u S_{R}$ の值は異なり、この二つが一義的に決定できないと予想されるからである。

(2)均質流モデルと分離流モデルによる $u s$ 予測

気液二相流中においても、粒子速度は式(2)で表わされるものと考える。·式(2)の右辺のそれ ぞれの項は、粒子の周りの流体をどのように考光るかで、その表わし方が異なってくる。そこ で、まず、均質流モデルと分離流モデルで気液二相流体を取り扱い、粒子速度を記述してみる。 均質流モデルの場合、流体の代表密度 $\rho_{F}$ は気体容積流量比 $\beta$ を用いて次式で定義される。

$$
\rho_{F}=\rho_{G} \beta+\rho_{L}(1-\beta)
$$




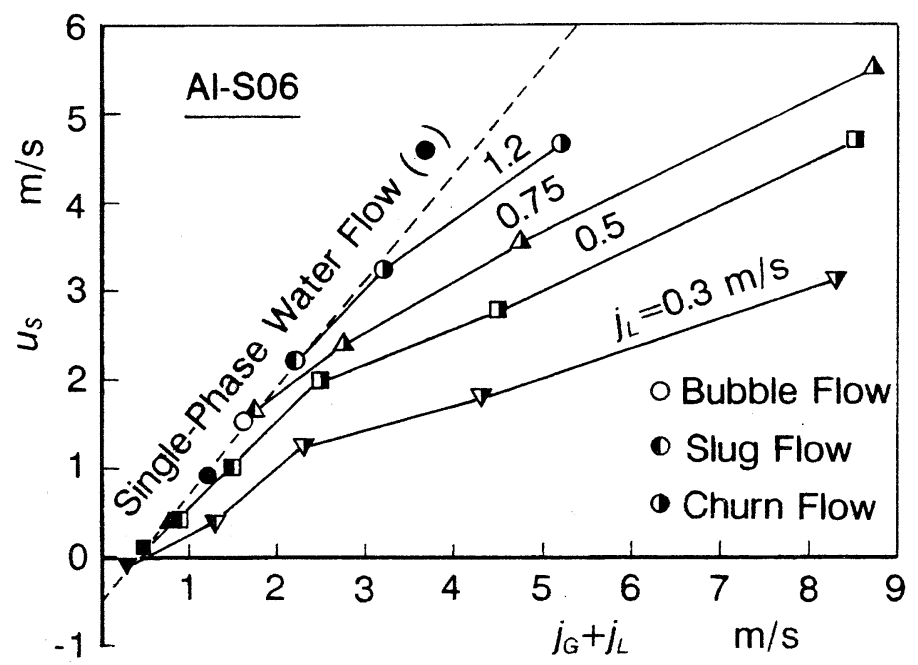

Fig. 5 (a) Experimental data on particle velocity in in two-phase gas-liquid flows ( $\mathrm{Al}-\mathrm{S} 06$ )

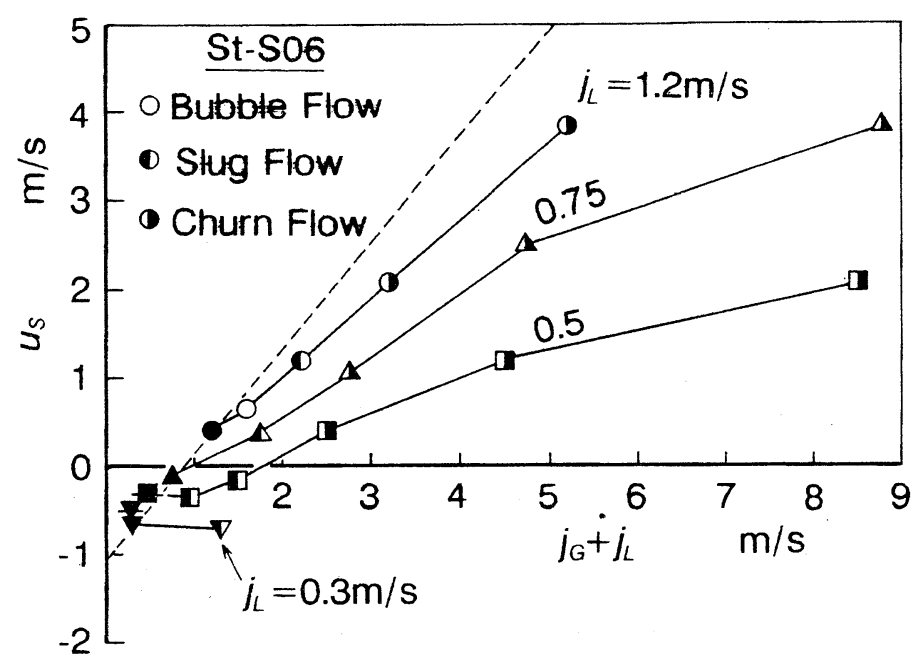

Fig. 5 (b) Experimental data on particle velocity in in two-phase gas-liquid flows (St-S06)

ただし、

$$
\beta=\frac{j_{G}}{j_{G}+j_{L}}
$$

流体の代表速度 $\mathrm{u}_{F}$ は、液単相流の式(3)になららと次式で表わされる。

$$
u_{F}=\frac{G_{F}}{\rho_{F} A}=j_{G}+j_{L}
$$


$u_{S R}$ は、流体密度 $\rho_{F}$ を式(6)で表わすときの壁面干渉沈降速度 $u s w$ であり、式(1) と式 (5)より 求められる。なお、均質流体と考えた場合も粒子は二ュートンの抵抗法則にしたがう領域にあ ると考光、C $D_{0}$ KはTable 1の値を用いることにする。

分離流モデルは、空気と水が流路断面を二分し、粒子は水中にのみ存在するとする考方方で ある。したがって、流体の代表速度 $u F$ は水の速度となり、ボイド率 $\alpha$ を用いて次式で表される。

$$
u_{F}=\frac{G_{L}}{\rho_{L} A(1-\alpha)}=\frac{j_{L}}{1-\alpha}
$$

$u S R$ は、粒子が常に水中にあると考えるから、水単相流中に拈ける壁面干涉沈降速度 $u$ swを取 ることになる。ちなみに、坂ロら る $^{6}$ と宇佐美ら ${ }^{23}$ は、粒子群の速度を与光る式として結果的にこ のモデルによる式を用いている。

以上の二つのモデルにより、式 (2)の係数を水単相流の場合と同様に $c=1.2$ として粒子速度 を計算してみた。な挍、分離流モデルに抒けるボイド率 $\alpha$ は、円管やいくつかの非円管内の空 気一水の垂直上昇二相流に拈いて、 $j_{L} \geqq 0.3 \mathrm{~m} / \mathrm{s}$ の領域での予測精度が高い、 ${ }^{21)} \operatorname{Smith}^{25)}$ にる 次式で求めた。式中のxはクオリティでめる。

$$
\begin{aligned}
\alpha=\left\{1+0.4 \frac{\rho_{G}}{\rho_{L}}\left(\frac{1}{x}-1\right)+0.6 \frac{\rho_{G}}{\rho_{L}}\left(\frac{1}{x}-1\right)\right. \\
\left.\times\left[\frac{\frac{\rho_{L}}{\rho_{G}}+0.4\left(\frac{1}{x}-1\right)}{1+0.4\left(\frac{1}{x}-1\right)}\right]^{0.5}\right\}^{-1}
\end{aligned}
$$

Fig.6にアルミニウムの Al-S06の粒子に関して、この二つのモデルによる計算結果と実験值の 比較の一例を示す。Fig. 6(a)〜 (f) は空気の容積流束 $j_{G}$ が異なっており、綎軸に粒子速度 $u s 、$

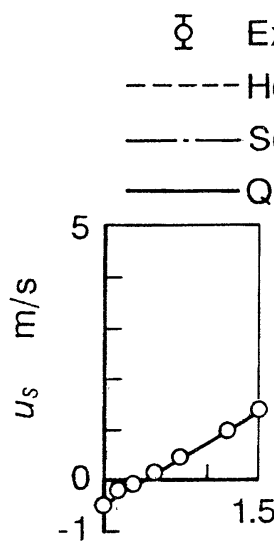

(a) $j_{G}=0 \mathrm{~m} / \mathrm{s}$

(b) $0.4 \mathrm{~m} / \mathrm{s}$

(c) $1.0 \mathrm{~m} / \mathrm{s}$
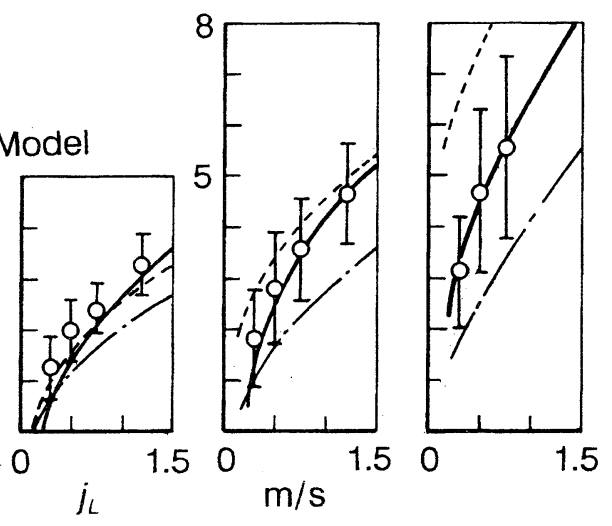

Fig. 6 Calculated results of particle velocity in two-phase gas-liquid flows ( $\mathrm{Al}-\mathrm{S} 06)$ 
横軸に水の容積流束 $j_{L}$ がとってある。データは一つの流れについて 15 個以上の粒子の速度を 測定し、その平均值を丸印で表わし、同時にそれらの標準偏差の幅も示している。Fig.6(f) j G $=8 \mathrm{~m} / \mathrm{s}$ の条件における $j_{L}>0.75 \mathrm{~m} / \mathrm{s}$ の領域では、助走距離が不足するためデータの採取を 行わなかった。破線と一点鎖線は、それぞれ均質流モデルと分離流モデルによる計算結果であ る。実線は、次に述べる準均質流モデルによる計算結果である。

破線で示した均質流モデルの結果は、 $j_{G}=2 \mathrm{~m} / \mathrm{s}$ 程度までは実験值と良く一致しているが、 これを越えると計算值が実験值を上まわり $j_{G}$ の増加とともにこの差が大きくなる。一点鎖線 の分離流モデルの結果は、 $j_{G}=1 \mathrm{~m} / \mathrm{s}$ 程度までは実験値と良く一致しているが、これを越える と均質流モデルとは逆に計算值が低くなり、jaの増加とともにこの差が大きくなる。すなわ ち、 $j_{G}$ の小さい気泡流やスラグ流の領域ではこれらの簡単なモデルで粒子速度を予測しうる が、 $j_{G}$ の大きいスラグ流やチャーン流の領域ではこれらのモデルによる粒子速度の予測精度 は低下する。なお、分離流モデルにおいて、壁面の影響を考慮する式(5)の管径 $D$ を $D(1-\alpha)^{0.5}$ と置き換えた試算を行ってみたが、効果は現われなかった。

坂ロら ${ }^{6}$ は、三相流中の粒子速度の整理式として次の式(11)(坂ロらの論文の式(18)) を提案 している。彼らは粒子は液相中に存在すると仮定しているので、前述のように彼らのモデルは 分離流モデルの範ちゅうに入る。

$$
\begin{aligned}
& \quad u_{S}=c_{S 3}{ }^{*}\left(j_{T}^{*}-j_{L f 3}^{*}\right)=c_{S 3}{ }^{*}\left\{j_{T}^{*}-\left(1-f_{S 3}^{*}\right) V_{f 3}^{*}\right\} \\
& \text { ここで、 } V_{S 3}{ }^{*} \text { は }
\end{aligned}
$$

$$
V_{f 3}{ }^{*}=K_{1} \exp \left(K_{2} \frac{f_{S 3}{ }^{*}}{1+f_{S 3}{ }^{*}}\right)
$$

である。定数 $K_{1}$ と $K_{2}$ は、管径 $(20$ と $30 \mathrm{~mm})$ や粒子の寸法 $(2.55 \sim 4.3 \mathrm{~mm})$ 、比重 $(2.38 \sim 2.64)$ などの実験条件に依存する值で、例えば $D=20.6 \mathrm{~mm} 、 d v=3.05 \mathrm{~mm}$ 、比重 $=2.64 、 j_{G}=0$ 〜 $0.849 \mathrm{~m} / \mathrm{s} 、 j_{L}=0.294 \sim 1.14 \mathrm{~m} / \mathrm{s} 、 j s=0 \sim 0.084 \mathrm{~m} / \mathrm{s}$ の場合、 $K_{1}=0.311 、 K_{2}=-2.51$ であ る。さらに、 $c s 3$ * も上述の実験条件に依存する值であり、粒子の体積率の関数で与えられて いる。なお、式(11)と式(12)の記号は坂ロらの的ものをそのまま用いた。これを、本研究の単 一粒子の場合に書き改めると次式となる。

$$
\begin{aligned}
& u_{S}=c_{S 3} *\left(\frac{j_{L}}{1-\alpha}-\frac{\tilde{j}_{L}}{1-\alpha}\right)=c_{S 3}^{*}\left(\frac{j_{L}}{1-\alpha}-V_{f 3}^{*}\right) \\
& V_{s 3}^{*}=K_{1}
\end{aligned}
$$

ただし、実験条件によって $c_{s 3}^{*}$ の值は変わることを坂ロらは報告しているので、式(13)の c s 3 と式(11)のそれとは必ずしも等価とは言えない。ちなみに三相流に対する $c{ }^{*}{ }^{*}$ の実験式 に粒子の体積率 $f_{s_{*}}^{*}=0$ 女代入すると単一粒子に対する式(13) の c s ${ }^{*}$ が求まると仮定すれ ば、その結果は $c s 3{ }^{*}=1.53^{8)}$ ないし1.62 ${ }^{6}$ となり、坂口らが理論の導出過程で考えている $c . s 3$ $=1.0 \sim 1.2^{6}$ とかなり異なる。このようなことから、坂ロらの式と本実験值を比較することは できなかった。なお、式(13)において $u s=0$ とした粒子の浮遊状態の場合には、係数 $c s 3$ に 依存しない気、液の浮遊容積流束 $\tilde{j}_{G} 、 \tilde{j}_{L}$ の関係式が得られるのでこれについては後出のFig. 
9に打いてさらに検討を試みる。

(3) 準均質流モデルによる $u s$ 予測

前項では気液二相流の代表的な二つのモデルで固体粒子の周りの流れを考え粒子速度を記述 してみたが、どちらのモデルも空気の容積流束 $j_{G}$ の大きい範囲で良い結果を与えなかった。 そこで、以下に粒子の平均速度の表示式として準均質流体モデルとでも称すべき一つのモデル を提案する。これは、粒子を輸送する気液二相流体の密度としてある仮想の密度（これを実効 密度と呼ぶ）を導入することによって、単相流の式(2)および式(1)、式 (5)をとのままの形で 活用しようとするものである。

いま、実効密度を $\rho_{E}$ とすれば、式(2)の右辺第 1 項の代表速度は次式で表わされる。

$$
u_{F}=\frac{G_{F}}{\rho_{E} A}=\frac{\rho_{G} j_{G}+\rho_{L} j_{L}}{\rho_{E}}
$$

さらに、 $u S_{R}$ は、式(1)と式(5)から次式となる。

$$
u_{S R}=-\left[1-2.5\left(\frac{d_{V}}{D}\right)^{2}+1.5\left(\frac{d_{V}}{D}\right)^{4}\right]^{0.5}\left[\frac{4 d_{V} g\left(\rho_{S}-\rho_{E}\right)}{3 C_{D} \rho_{E}}\right]^{0.5}
$$

ここで、抗力係数 $C_{D}$ には、均質流モデルと同様にTable 1の值を用いる。

式(2)の係数 $c$ を1.2とし、これと式(15)、式(16)を連立させ、球形粒子に関する実験值を用い 実効密度 $\rho_{E}$ を求めた結果をFig.7 7 示す。図は次式の無次元実効密度差 $\Delta \rho_{E}^{\star}$ と気液二相流の 無次元平均密度差 $\Delta \rho_{T P}^{\star}$ との関係を示したものである。

$$
\begin{aligned}
& \Delta \rho_{E}{ }^{\star}=\frac{\rho_{E}-\rho_{G}}{\rho_{L}-\rho_{G}} \\
& \Delta \rho_{T P}^{\star}=\frac{\rho_{T P}-\rho_{G}}{\rho_{L}-\rho_{G}}
\end{aligned}
$$

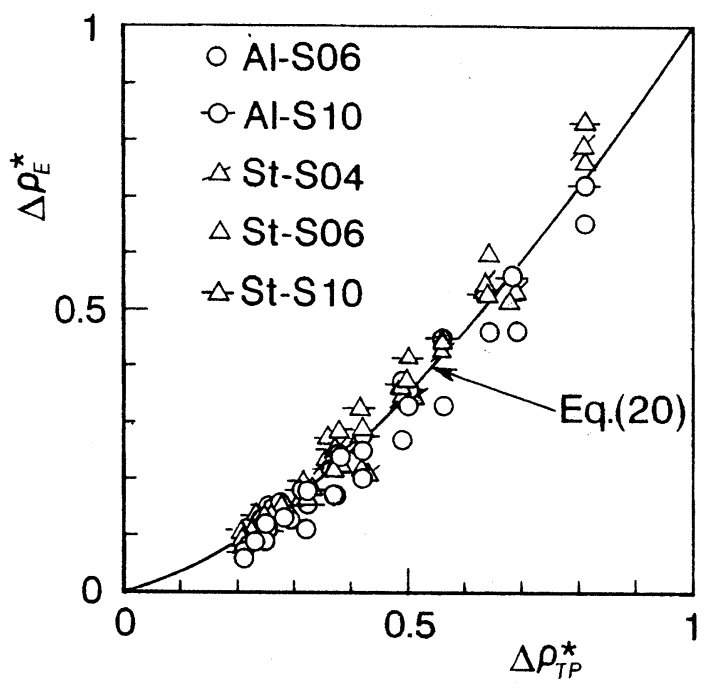

Fig.7 Effective density of two-phase gas-liquid flow 
ここで、気液二相流の平均密度 $\rho T_{P}$ は、

$$
\rho_{T P}=\rho_{G} \alpha+\rho_{L}(1-\alpha)
$$

である。なお、ボイド率 $\alpha$ は式(10)によった。粒子の密度と寸法に大きな差があるにもかかわ らず、 $\Delta \rho_{E}^{\star}$ と $\Delta \rho_{T P}{ }^{\star}$ との関係は次式で表わすことができる。

$$
\Delta \rho_{E}^{\star}=\Delta \rho_{T P}^{\star 1.5}
$$

前述したFig.6における実線は、式(20)で表わされた実効密度 $\rho_{E}$ を用い、 $c=1.2$ とした式 （2）に式(15)と式(16)を代入して求めた計算結果である。実験式(20)の基になった実験の一つ

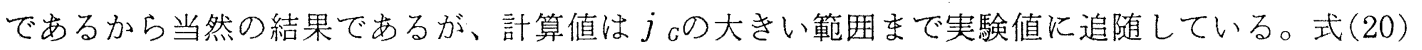
は球形以外の粒子についてもよい結果を与える。Fig.8は、アルミニウム立方体における計算 值と実験值とを比較したものである。両者は45度の実線上にほぼ乗っており、形状がこの程度 変化しても良い予測值を与光ることが分かる。

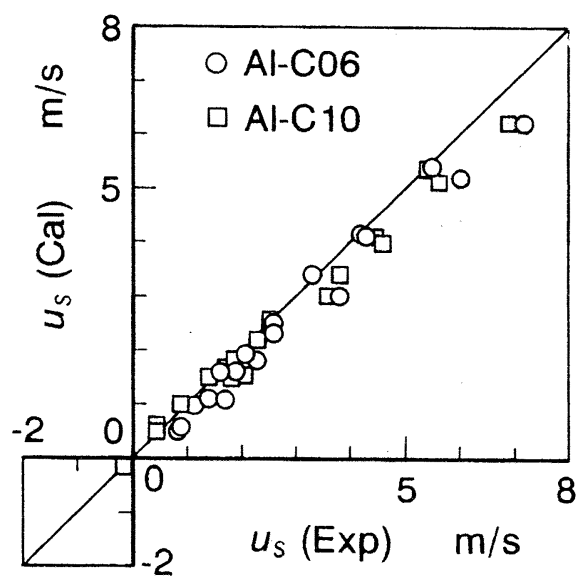

Fig. 8 Particle velocities predicted by the quasi-homogeneous flow model vs.

the experimental data in the cases of aluminous cubes

$$
\left(j_{G}=0.4 \sim 8.0 \mathrm{~m} / \mathrm{s} 、 j_{L}=0.15 \sim 1.2 \mathrm{~m} / \mathrm{s}\right)
$$

Fig.9は、上に提案した計算法により三種類の粒子の浮遊容積流束を求め実験值と比較した ものである。横軸は浮遊状態の空気の容積流束 $\tilde{j}_{G 、}$ 綎軸は水の容積流束 $\tilde{j}_{L}$ とってある。つ まり、実験点の示す $\left(\tilde{j}_{G}, \tilde{j}_{L}\right)$ の值で粒子が浮遊状態になる。実線は前述の準均質流モデルに よる計算結果であり、一点鎖線は次に述べる坂ロら ${ }^{6), 8}$ に基づく計算結果である。また、図中に はTaitelら ${ }^{22} に よ る$ 流動様式の判別を示している。実線と実験值はどの領域においても良く一致 している。したがって、本報で提案するモデルは浮遊容積流束の予測においても罗当性はある といえる。

次に、坂口らのモデル ${ }^{6), 8}$ による浮遊容積流束の予測結果について述べる。3.2(2) 項で述べ た $V_{s 3}^{*}$ を仮に液単相流中に拈ける単一粒子の浮遊容積流束の実験值 $\widetilde{\mathbf{j}}_{L}, 0$ と等しいとすれば、式 (13)より

$$
\tilde{j}_{L}=(1-\alpha) \tilde{j}_{L, O}
$$




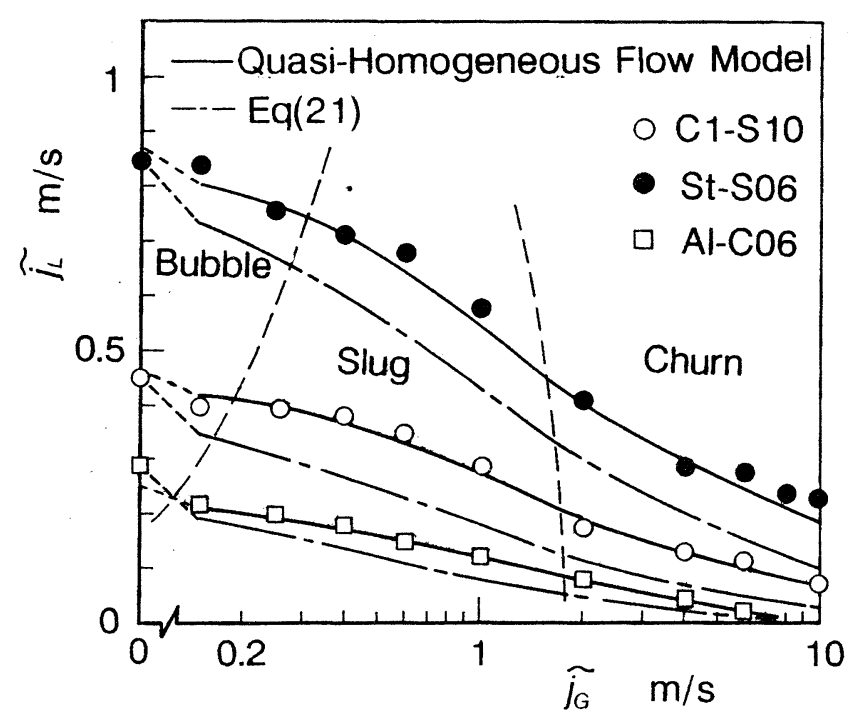

Fig. 9 Comparison of experimental and predicted relsuts for the floating volumetric fluxes

なる式が得られる。ここで、 $\alpha$ は粒子が浮遊する流れのボイド率であり、気・液の浮遊容積流 束 $\tilde{j}_{G}$ と $\tilde{j}_{L}$ の関数と考えられる。そこで、前述のSmithの式、式(10)を $\alpha$ の計算に用いれば、 式(21)から繰り返し計算( 試行錯䛊法)によって任意の $\tilde{j}_{G}$ に対する $\tilde{j}_{L}$ が得られる。このように して得られた計算結果がFig.9に一点鎖線で示されている。この計算值は定性的には実験值の 傾向を良く表わしている。これは、坂口らの記述式の出発点となっている分離流モデルが三相 流の本質の一面を表わすものと理解でさる。ただし、 $\widetilde{j}_{L}$, 。に本実験值を用いたにもかかわら ず定量的な一致は十分ではないので、 $\tilde{j}_{G}$ と $\tilde{j}_{L}$ の関係を坂口らの式を用いてょり正確に求める

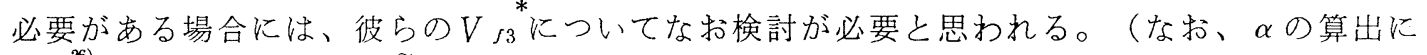
赤川 ${ }^{26)}$ の式を用いた場合も $\widetilde{j}_{G}<2 \mathrm{~m} / \mathrm{s}$ ではSmithの式の場合とほぼ同じであった。）

気液二相流中の単一粒子の速度は、気液二相流の実効密度を用いることで良い予測結果を得 ることができた。この方法を三相流に拡張する場合には、式 (18)中の $\rho_{T P} k 三$ 相流の平均密度 を代入すること、式(2)の右辺第 2 項に粒子の相互干渉の影響を考慮することなどで対応でき ると予想される。

\section{4. 結言}

固気液三相流中の粒子群の速度に関する知見を得るための第一着手として、垂直管内気液二 相流中の単一粒子の速度を調查した。 $d v / D=0.154 \sim 0.385 、 \rho_{S}=1190 \sim 7850 \mathrm{~kg} / \mathrm{m}^{3}$ の球形 および立方体の粒子について、 $j_{G}=0 \sim 10 \mathrm{~m} / \mathrm{s} 、 j_{L}=0 \sim 1.5 \mathrm{~m} / \mathrm{s}$ の気、液の流量範囲で実験 を行い検討した結果、次の結論を得た。

（1）気液二相流中の単一粒子の速度はごく短い時間で大きく变動しているが、実測定洔間 の総計が 12 秒を越光ると平均速度は一定值に収束する。

（2）水単相流中の単一粒子の速度は、ジグザグ運動によって壁面で跳ねて下降する粒子を

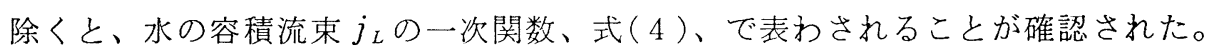

（3）気液二相流の場合、均質流モデルあるいは分離流モデルは、ボイド率の高いスラグ流 やチャーン流において粒子速度の予測精度が悪くなる。 
（4）準均質流モデルを提案した。このモデルによる粒子速度は、 $c=1.2$ とした式( 2 )に 式(15),式(16)抢よび球形粒子の実験データより求められた実効密度 $\rho_{E}$ を表わす式 (20) を代入して計算される。これによる立方体粒子速度の予測值も実験值と良く一致する。

最後に、本研究を行うに当り実験面で協力をいただいた当洔の熊本大学学生黒岩久能君に感 謝の意を表します。

\section{参考文献}

（1）たとえば森川敬信：流体一固体二相流、日刊工業新聞社、東京 (1979).

(2) 坂口忠司：機論、Vol.54, No.503,1549-1554(1988).

(3) 植木士郎：採鉱と保安、Vol.25, No.8,393-405(1979).

（4）都田昌之ほか 4 名：化学工学論文集、Vol.8,No.4,380-386(1982).

（5）平川良一洁か 4 名：日本釷業会昭和62年度秋季例会講演論文集、(1982).

（6）坂口忠司活か 5 名：機論、Vol.53,No.487,1040-1046(1987).

(7) Sakaguchi, T.et al.:Exp.Heat Trans.,Fluid Mech., Thermodynamics 1988, Ed.Shan, R.K., Ganic,E.N., Yang, K.T.,1353-1360.

（8）坂口忠司弫 3 名：第24回日本伝熱シンポジウム講演論文集、467-469(1987).

(9) Sakaguchi, T.et al.: Memoirs Fac.Engng.Kobe Univ. ,35,47-84(1988).

(10) Schlichting, H.: Boundary-Layer Theory, McGraw-Hill, New York(1955).

(11) Wadell,H.:J.Franklin Inst., Vol.217,459-490(1934).

(12) 都田昌之ほか 3 名：化学工学、Vol.33,No.1,67-73(1969).

(13) Govier, G.W., Aziz,K.:The Flow of Complex Mixtures in Pipes, Von Nostrand Reinhold, New York(1972).

(14) Engelmann,H.E.:Meerestechnik, Vol.9, No.4,115-123(1978).

(15) Ohashi,H.et al.: J.Chem Eng., Japan, Vol.13, No.5,343-349(1980).

（16）北原良哉ほか 3 名：採鉱と保安、Vol.31,No.3,146-157(1985).

（17）山崎哲生活か 4 名：採鉱と保安、Vol.33,No.4,169-177(1987).

(18) Munroe,H.S.: Trans. Am.Min.Eng., Vol.17,637-659(1888).

（19）鮎川恭三、越智順治、新名静夫：機論、Vol.35,280,2357-2364(1969).

（20）野田佳六、川島俊夫、吉沢幸雄：日本鉱業会誌、Vol.86,No.981,13-18(1970).

(21) 奥田教海: 機論、Vol.41,No.342,559-567(1975).

(22) Taitel, Y., Barnea, D., Dukler, A.E. : AIChE J., Vol.26, No.3 ,345-354(1980).

（23）宇佐美毅、斉藤隆之：公害資源研究所報告、Vol.38, 1-108(1986).

（24）佐田富道雄、猿渡真一、佐藤泰生：機論、Vol.48, No.434,1893-1900(1982).

(25) Smith, S.L.: Proc.Inst.Mech.Eng., Vol.184, No.36,647-664(1969-70).

(26) 赤川浩爾：機論、Vol.23, No.128,285-291(1957). 